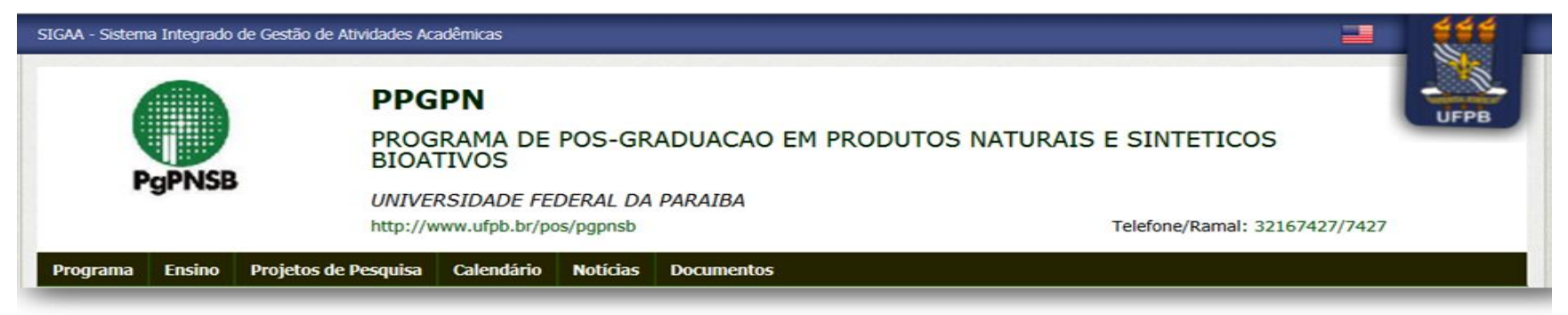

\title{
SciForum
}

MOL2NET

\section{Quality control and quantitation of catechin and epicatechin from leaves of Maytenus rigida Mart}

Diego Igor Alves Fernandes de Araújo ${ }^{1, *}$, Anny Palloma de Lima Arruda Fernandes² ${ }^{2}$ Rodrigo Silva de Andrade ${ }^{1}$, Josean Fechine Tavares ${ }^{1}$ and Marcelo Sobral da Silva ${ }^{1}$

1 Postgraduate Program in Natural and Synthetic Bioactive Products, Health Sciences Centre, Federal University of Paraiba, João Pessoa, PB, Brazil; E-Mail: diego_igor@ltf.ufpb.br; rodrigo@ltf.ufpb.br; josean@1tf.ufpb.br; marcelosobral@ltf.ufpb.br

2 Health Sciences Centre, Federal University of Paraiba, João Pessoa, PB, Brazil; E-Mails: anypallom@gmail.com

* Author to whom correspondence should be addressed; E-Mail: diego_igor@ltf.ufpb.br; Tel.: +55-083-111-111.

\section{Received: / Accepted: / Published:}

\begin{abstract}
Maytenus rigida Mart belongs to the family Celastraceae, formed by 106 genera and 1.300 species, that are widely distributed in tropical and subtropical regions. The species is distributed in Caatinga region of northeastern Brazil in the states of Sergipe, Paraiba and Pernambuco. Maytenus rigida is popularly known as bom nome or chapéu de couro. It is used in folk medicine for gastritis and gastric ulcer. The main secondary metabolites reported for this species are pentacyclic triterpenes, flavonoids and alkaloids. This work aimed to evaluate the quality control of raw material and the quantification of catechin and epicatechin by High Performance Liquid Chromatography (HPLC) in Maytenus rigida crude ethanolic extract (CEE) obtained from leaves. The plant material was collected in the municipal district of Boa Vista - PB in June of 2018. Physicochemical assays were developed with leaves: Determination of loss on drying, total ashes, limit assay for heavy metals, bulk density, following the recommendations of the $5^{\text {th }}$ Brazilian Pharmacopoeia. The content of total phenolic compounds was determined using the Folin-Ciocalteu method and total flavonoids was measured using the colorimetric method with $\mathrm{AlCl}_{3}$ with CEE. The quantitation of (+)-Catechin and (-)-Epicatechin was performed with a validated method previously developed. M. rigida leaves presented $5.9 \% \pm$ 0.143 of water content, $5.10 \% \pm 0.136$ of total ashes, $<10 \mathrm{ppm}$ of heavy metals and $0.40 \mathrm{~g} / \mathrm{mL}$ of bulk density. The total phenolic content was $187.52 \pm 2.01 \mu \mathrm{g}$ EAG/mg and the flavonoid content was $88.80 \pm 1.47 \mu \mathrm{g} \mathrm{EQ} / \mathrm{mg}$. The evaluation of CEE showed the presence of $7.79 \mu \mathrm{g}$ of (+)-Catechin/mg and $6.04 \mu \mathrm{g}$ of (-)-Epicatechin/mg. The quality control analyzes performed with $M$. rigida established a better profile for the characterization of the drug. This study confirms the applicability of method for the quantification of phenolic compounds in extracts of Maytenus rigida.
\end{abstract}

Keywords: Maytenus rigida; quality control; catechins

Mol2Net YouTube channel: http://bit.do/mol2net-tube 


\section{Introduction}

Maytenus rigida Mart., Celastraceae, is an evergreen tree that is endemic to the Caatinga region from Northeastern Brazil and is found in the states of Sergipe, Paraiba and Pernambuco. This species is popularly known as "bom-nome" and "chapéu-de-couro" and is used in folk medicine as analgesic, anti-inflammatory, healing and for the treatment of gastritis and gastric ulcer (Santos et al., 2011).

There are many reports about the phytochemical composition of $M$. rigida leaves and barks, especially catechin, epicatechin, terpenoids and proanthocyanidins (Almeida et al., 2005; Estevam, 2006) and pharmacological activities, such as antimicrobial, antinociceptive, antioxidant, antiulcerogenic and antidiarrheal (Estevam, 2006; Santos, 2008, Santos et al., 2011).

One important aspect for the efficiency of the treatment is the quality control of herbal medicine products and the determination of its chemical markers (Marques et al., 2013).

The aim of this work was to evaluate the quality control of raw material and the quantification of chemical markers by HPLC from $M$. rigida crude ethanolic extract (CEE) obtained from its leaves.

\section{Results and Discussion}

The determination of loss on drying and water content are important to evaluate the quality of vegetal raw materials, as moisture content favors the development of microorganisms, as well as enzymatic activities. The values found for the plant drug $M$. rigida $(5.9 \% \pm 0.143)$ are in accordance with the specified limits in Brazilian Pharmacopoeia (Brazil, 2010).

The second parameter evaluated was the total ashes content, this evaluation aims to determine the content of inorganic impurities and constituents contained in organic substances. The raw material of $M$. rigida presented $(5.10 \% \pm$ 0.136 ) of total ashes, content below the specified in the compendium (8 - 14\%).

Bulk density consists in an important parameter to the extraction process control of vegetable raw materials, the results obtained for dry material in study was $0.40 \mathrm{~g} / \mathrm{mL}$. While there are no reference parameters for this species, the values found might be considered normal.
The proximity of highways as well as water quality by pollutants that are conducted by rainwater, can affect plant (Freire, 2005). The limit assay for heavy metals provided satisfactory results (below $10 \mathrm{ppm}$ ).

The total phenolic content was $187.52 \pm 2.01 \mu \mathrm{g}$ $\mathrm{EAG} / \mathrm{mg}$ and the flavonoid content was $88.80 \pm$ $1.47 \mu \mathrm{g} \mathrm{EQ} / \mathrm{mg}$. These results confirm the abundance of the polyphenolic content found in the species and demonstrate its pharmacological potential, since these metabolites are mainly related to antimicrobial, antiulcerogenic and antioxidant activities (Santos, 2008; Santos et al., 2011). The evaluation of CEE showed the presence of $7.79 \mu \mathrm{g}$ of (+)-Catechin/mg and 6.04 $\mu \mathrm{g}$ of (-)-Epicatechin/mg, these are important results considering that flavan-3-ols may be involved in the anti-inflammatory and gastroprotective process (Santos, 2008).

\section{Materials and Methods}

The leaves of Maytenus rigida were collected in the city of Boa Vista, Paraiba, Brazil, in June of 2018. The plant materials were dried at temperature of $40{ }^{\circ} \mathrm{C}$, for 96 hours, and then powdered in a mill.

\section{Physicochemical characterization of the plant material}

The physicochemical assays were developed: determination of loss on drying, total ashes, limit assay for heavy metals and bulk density in accordance with the $5^{\text {th }}$ Brazilian Pharmacopoeia (Brazil, 2010).

\section{Obtaining plant extracts}

The leaves of Maytenus rigida were submitted to an extraction process by maceration method, with ethanol 95\%. Three extractions were developed, replacing the solvent every 72 hours. The extraction solution obtained was submitted to rotary evaporator at an average temperature of $40{ }^{\circ} \mathrm{C}$.

\section{Determination of total phenolic compounds and total flavonoids}

The content of total phenolic compounds (TPC) was measured based on the method described by Singleton et al (1999). The total 
flavonoids (TF) were determined using the colorimetric method by metallic complexation described by Schmidt and Ortega (1983). All samples were performed in triplicates.

\section{Quantitation of (+)-Catechin and (-)- Epicatechin}

The markers were quantified in CEE of $M$. rigida by HPLC coupled with diode array detection (HPLC-DAD). Analytical separation was performed on a Prominence Shimadzu LC20AT quaternary pump, a photodiode array detector SPD-M20 A and a Shim-pack ${ }^{\circledR}$ column C18 $(150 \times 4.6 \mathrm{~mm} \times 5 \mu \mathrm{m})$, with pre-column Shim-pack G® ODS (4 x $3.0 \mathrm{~mm}$ x $5 \mu \mathrm{m})$. HPLC data acquisition was performed by LC Solution software. The optimized analytical separations of (+)-Catechin and (-)-Epicatechin were carried out using a mobile phase of $0.1 \%$ phosphoric acid in water (A) and acetonitrile (B) with the following method: $0-30 \mathrm{~min}: 5$ to $25 \%$ of $\mathrm{B}$; $30-40$ min: 25 to $100 \%$ of $\mathrm{B}$; $40-50 \mathrm{~min}$ : $100 \%$ of $\mathrm{B} ; 50-55 \mathrm{~min}$ : 100 to $5 \%$ of $\mathrm{B} ; 55-60$ min: $5 \%$ of B. A flow rate of $1.0 \mathrm{~mL} / \mathrm{min}$ at $40{ }^{\circ} \mathrm{C}$ and an injection volume of $20 \mu \mathrm{L}$ were employed. The UV spectra were recorded at 280 nm. (+)-Catechin and (-)-Epicatechin standards (> 99\%) were purchased by Phytolab®. The markers were quantified by the equation obtained by linear regression. (+)-Catequin $y=7426,2 \mathrm{x}+$ $607,0(\mathrm{r}=0,9999)$ and $(-)$-Epicatechin $\mathrm{y}=$ $17877 \mathrm{x}-10588(\mathrm{r}=0,9997)$.

\section{Conclusions}

The quality control analyzes performed with $M$. rigida established a better profile for the characterization of the plant material. The results demonstrated that the evaluated parameters were in accordance with the $5^{\text {th }}$ Brazilian Pharmacopoeia specifications. The TPC and TF contents supported its applicability in folk medicine. The previously validated HPLC method for quantitation of (+)-Catechin and (-)Epicatechin is suitable to measure the markers and can be used on another species of Maytenus genera.

\section{Acknowledgments}

This study was supported by Capes (Brazil) for scholarships and research fellowships.

\section{Conflicts of Interest}

The authors declare no conflict of interest.

\section{References and Notes}

1. Almeida, C. F. C. et al. Life strategy and chemical composition as predictors of the selection of medicinal plants from the caatinga (Northeast Brazil). Journal of the Ethnopharmacology 2005, $62,127-42$.

2. Brazil. Agência Nacional de Vigilância Sanitária. Farmacopéia Brasileira, 5 ed., 1. Brasília-DF, 2010.

3. Estevam, C. S. Estudo fitoquímico biomonitorado da entrecasca de Maytenus rigida Mart. (Celastraceae). Doctorate in Chemistry, Federal University of Alagoas, Maceió, 2006.

4. Freire, M.F. Metais pesados e plantas medicinais. Rev. Ciênc. Agron. 2005, 8.

5. Marques, G., Leão, W., Lyra, M. et al. Comparative evaluation of UV/VIS and HPLC analytical methodologies applied for quantification of flavonoids from leaves of Bauhinia forficata. Brazilian Journal of Pharmacognosy 2013, 23, 51-57.

6. Santos, V. L. Avaliação da atividade antiulcerogênica, antidiarréica e antiespasmódica do extrato etanólico bruto e fase acetato de etila obtidos da entrecasca do caule de Maytenus rigida Mart. (celastraceae) em modelos animais. Doctorate in Pharmacology, Federal University of Paraiba, Joao Pessoa-PB, 2008.

7. Santos, V. L; Souza, M. F. V; Batista, L. M, et al. Avaliação da atividade antimicrobiana de Maytenus rigida Mart. (Celastraceae). Revista Brasileira de Plantas Medicinais 2011, 13, 68-72.

8. Schmidt, P. C.; Ortega, G. G. Passionsblumenkraut. bestimmung des gesamtflavonoidgehaltes von Passiflorae herba. Deutsche Apotheker Zeitung 1983, 133, 17-26.

9. Singleton, V. L.; Orthofer, R.; Lamuela-Raventos, R. M. Analysis of total phenols and other oxidation substrates and antioxidants by means of Folin-Ciocalteu reagent. Methods in Enzymology 1999, 299, 152-178. 